\title{
Several Cretaceous Oil and Gas Indications, Recently found in Hokkaido
}

\author{
By \\ Sutekazu NAgaO* and Toshio TANAKA*
}

(Manuscript Received March 1st, 1969)

\section{Introduction}

Recent developement of the Cretaceous oil field in the world is quite remarkable. Though, we have no productive oil field in Japan, imported oil from the Middle and Near East, which shows $85 \%$ of the whole import is mostly derived from Cretaceous field. The Cretaceous sediments in Japan are found almost everywhere of the island, however, oil and gas indications are entirely concentrated in Hokkaido excepting one in the Himenoura formation in Kyushu. The Cretaceous sediment in Hokkaido occupies wide area from Soya to Urakawa, $375 \mathrm{~km}$ from north to south, $42 \mathrm{~km}$ from east to west, and its thick part is estimated about $12,000 \mathrm{~m}$. These sediments are mostly marine, excepting very small part of the whole sediments, and are famous of their ammonite fossil. Their stratigraphical relation, fossil subdivision, geological structure are studied by many geologists and palaeontologists. In those Cretaceous sediments in Hokkaido, many oil and gas indications are hitherto reported, however, the Cretaceous study from the point of oil geology is just started from very recent.

In this paper the writer describes several new oil and gas indecations found during last year (1943), and also want to relate the oil and gas problem in Hokkaido.

\section{General view of the Cretaceous formation in Hokkaido}

From the standpoint of oil geology, the development of typical Cretaceous formation is extending from north to south in a large sedimentary basin which is called the Yezo geosyncline, and the

\footnotetext{
* Sanko Consultant K.K.
}

sediment from Teshio to Horokanai in Tenpoku district is considered to be thick. In Horokanai and Soeushinai district the Hakobuchi formation was eroded out, however, the formation from the upper Yezo group to the Lower Yezo group are estimated about $10,000 \mathrm{~m}$ in thickness.

The typical Cretaceous sedimentation from the Hakobuchi to the Lower Yezo can be observed in Teshio-Abeshinai, Oyubari and IshikariKanayama and are calculated $5,000-7,000 \mathrm{~m}$ in thickness, excepting the Sorachi group.

The Mesozoic formation in Hokkaido is divided typically as follows (in ascending order). The Hidaka group, the Sorachi group, the Yezo group and Hakobuchi group. However, some lower part of the Hidaka group may be correlated to Palaeozoic. The Nemuro group in the eastern Hokkaido is considered from Upper Yezo to Danian.

List 1

\begin{tabular}{|c|l|l|}
\hline \multirow{4}{*}{ Gretaceous } & \multicolumn{2}{|c|}{ Hakobuchi Group } \\
\cline { 3 - 3 } & Yezo Group & Upper Yezo G. \\
\cline { 3 - 3 } & & Middle Yezo G. \\
\hline $\begin{array}{c}\text { Jura } \\
?\end{array}$ & Sorachi Group & Lower Yezo G. \\
\hline & & Shuyubari G. \\
\hline & Hidaka Graup & Kamui G. \\
\hline
\end{tabular}

No fossil remain has hitherto been reported in the Hidaka group (excepting radiolaria.) In the Yamabe group, lower part of the Sorachi group, following fossil were reported, and considered to be as the Torinosu horizon. 
PL. 1. Cretaceous Sedimentary Section from Soya to Urakawa

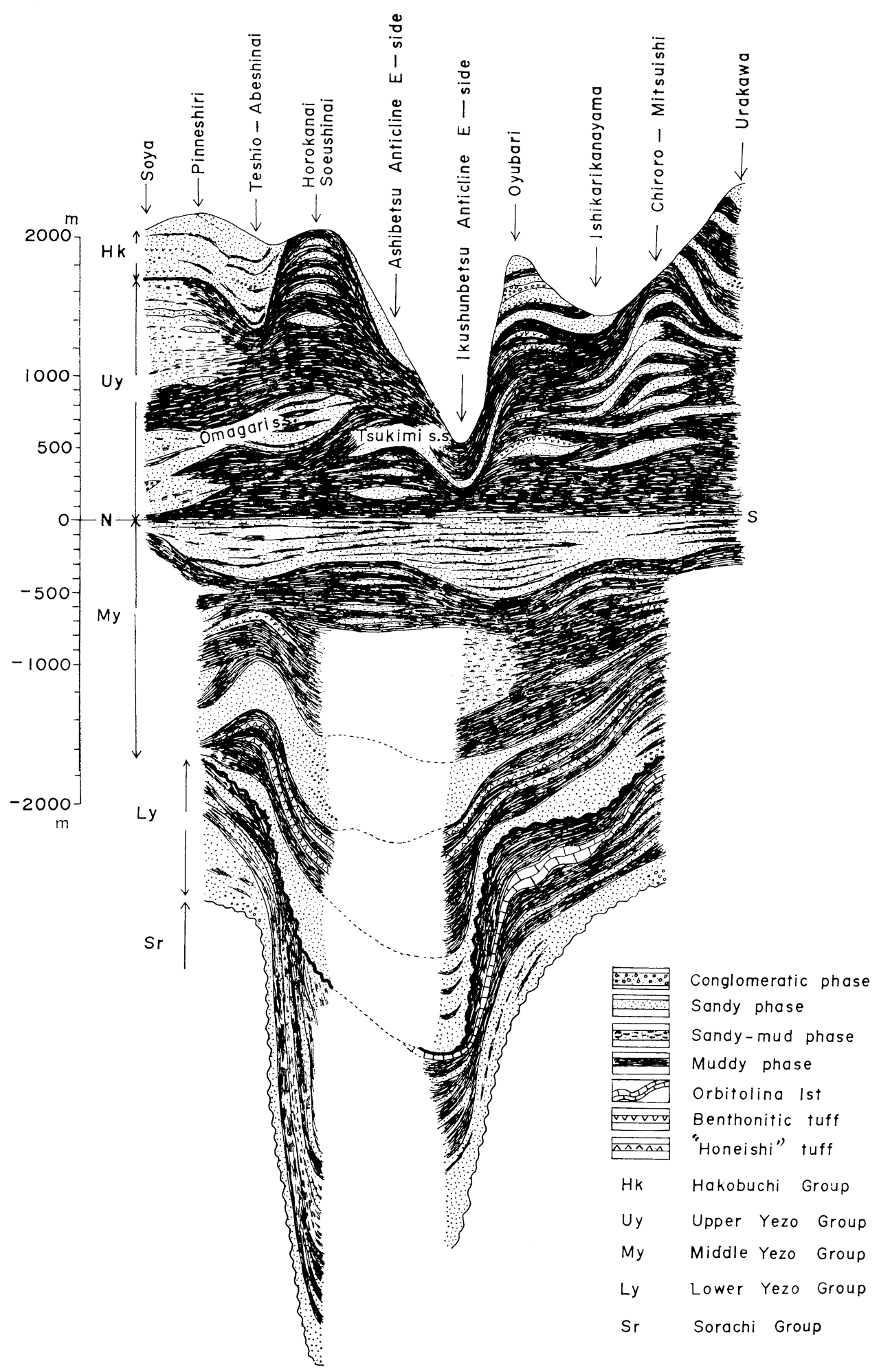


Heptastylopris asiatica

YABE et SugIYAMA

Circoporella semiclathrata

HAYASAKA

Pycnoporidiun lobatum

YABE et SUgIYAMA

Nipponophyx ramosum

YABE et SUGIYAMA

Yezoactinia shotombetsuensis

HASHIMOTO

Tosastroma yabei HASHIMOTO

Milleporella fassiculate tenue

HASHIMOTO

Milleporidium kitamiensis

HASHIMOTO

On the otherhand, in the Shuyubari group, following fossil were reported in the Rebun formation which is correlated to upper Sorachi, and is considered to be Lower Cretaceous.

Stromatomorpha rebunenisis

HASHIMOTO \& NAGAO

Spongiomorpha asiatica

YABE \& SUGIYAMA

Zamiophyllum buccianum

DKR.

etc.

So the Cretaceous formation in Hokkaido is from the Shuyubari stage.

The Shuyubari group is mostly consisted of sandstone and shale, containing thin layer of shalstein, excepting Rebun and Kumaneshiri area.

The shale material of the Shuyubari group is almost black and its organic content is comparatively profitable among the other Cretaceous shales.

The Yezo group which overlies the Sorachi group unconformably, consists from conglomerate, sandstone and shale, limestone layer which is called the Orbitolina limestone is intercalated in the upper horizon of the Lower Yezo group. This limestone is very famous as "stink-kalk" in Shimanoshita of Sorachi district. Orbitolina limestone in Hokkaido was found from the central to the southernpart continuously, its northern limit is Chikabumi near Asahigawa. Hower, Dr. Matsumoto once reported its exsistence in Keton of south Sakha-lin, and Orbitolina cfr. concava was found by a Soviet geologist, so true nothern limit of Orbitolina limestone in the "YezoSakhalin Sedimentary Basin" shall be extend more northward until Keton. And its absence may due to the basal unconformity of the Middle
Yezo group.

Black shale of the Lower Yezo group shows the highest percentage of organic content among the Yezo group shales.

Owing to the influence of basal unconformity of the Middle Yezo group, some parts of the central Hokkaido have very thin Middle Yezo sediment.

So it is very important to understand the scale and extention of the Middle Yezo unconformity for discussing cretaceous oil of this island.

Oil and gas indication of the Lower Yezo group was found in serpentine rock of Utonai-gawa, Teshio, and this indication is considered to be derived from the Kamiji Shale.

Seeing from the high percentage of orgainc content of the Kamiji shale, it is hopeful that the oil derived from the Kamiji shale was reserved in the Moehoro sandstone, which covers the Kamiji Shale unconformably, and overlain by the Shirataki shale as a cap rock.

In the longitudinal section of the central Hokkaido, the variation of the thickness of the Middle Yezo group form north to south is estimated about $1,600 \mathrm{~m}$ in Soya district, 3,500m in Soeushinai and Oyubari, and $2,000 \mathrm{~m}$ in Chiroro. The orgainc content of shale in the Middle Yezo group shows a little bit lower figure than that of the Lower Yezo group. The combination of source rock and reservoir in the Middle Yezo is very

List 2 Typical classification of the Yezo group in northern Hokkaido

\begin{tabular}{|c|c|c|}
\hline \multirow{3}{*}{$\begin{array}{l}\text { upper } \\
\text { Yezo }\end{array}$} & $\begin{array}{l}\text { Osoushinai } \\
\text { Formaton }\end{array}$ & mainly mudstone \\
\hline & Omagari $\mathrm{F}$. & sandstone and conglomerate \\
\hline & $\begin{array}{l}\text { Nishi-chirashinai } \\
\text { F. }\end{array}$ & mudstone and tuff \\
\hline \multirow{5}{*}{$\begin{array}{l}\text { middle } \\
\text { Yezo }\end{array}$} & Saku F. & $\begin{array}{l}\text { sandstone, shale, } \\
\text { conglomerate alternation }\end{array}$ \\
\hline & Sakugawa F. & mudstone \\
\hline & Sakotandake F. & sandstone \\
\hline & Shirataki F. & black shale, liparitic tuff \\
\hline & Moehoro F. & $\begin{array}{l}\text { sandstone, basal } \\
\text { conglomerate }\end{array}$ \\
\hline \multirow{2}{*}{ Lower } & Kamiji F. & black shale \\
\hline & Onodera F. & $\begin{array}{l}\text { sandstone, basal } \\
\text { conglomerate }\end{array}$ \\
\hline
\end{tabular}


favourable because of large scale alternation of sandstone and shale, and also about $50 \%$ of oil and gas indications which have been found in the Yezo group is in this horizon.

The upper Yezo Group is generaly consist of muddy phase excepting Soya district, intercalating lenticular sandstone. From Horokanai to Soeushinai, the thickness is estimated about $2,100 \mathrm{~m}$ and this is the thickest we can see this island.

In the Ashibetsu anticline, the eastern flank is $1,000 \mathrm{~m}$ thick, and the western flank is only $400 \mathrm{~m}$.

In the Ikushunbetsu anticline, we can see the same feature of difference, namely, its eastern flank is at least $1,000 \mathrm{~m}$ thick, and the western flank is only $500 \mathrm{~m}$ thick. Very favourable reservoir, as the Omagari sandstone or the Tsukimi sandstone is widely distributed in the muddy phasis of the Upper Yezo Group. These sandstone layers were sealed up by compact mudstone and its porosity and permeability are very similar to the sandstone of Akita and Niigata oil fields. The Hakobachi Group is all predominantly sandy phasis excepting the Chinomigawa formation in Urakawa area.

The thickness of the Hakobuchi group is generally $300-500 \mathrm{~m}$, though the upper part is eroded out. The Chinomigawa formation is exceptionary thick $(1,100 \mathrm{~m})$, and rather muddy than any other Hakobuchi formation in Hokkaido.

We still have several diffident points against the Hakobuchi formation. The relation between the Hakobuchi and the upper Yezo is reported sometimes conformable and sometimes unconformable.

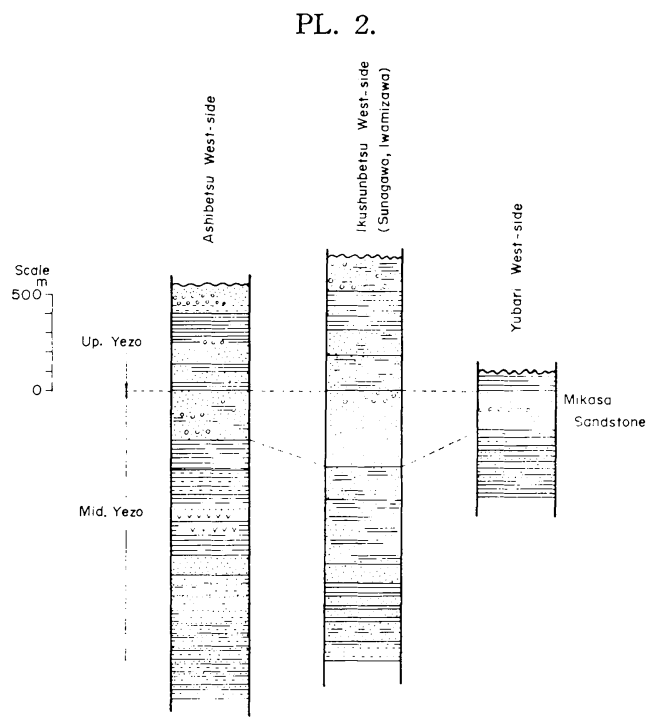

However, seeing from fossil evidence there will be no remarkable time break between them.

Many gas and oil indications were ascertained in this formation, especially in the southern part of this island.

The Nemuro formation, which is almost equivalent to upper Yezo-Danian is widely distributed in Nemuro peninsula, and extending further westward to Kushuro untill Kushiro and Tokachi border. This formation is accumulated in a different sedimentary basin to the Yezo geosyncline, and its basement rock is shalstein of the Yamabe stage.

Fossil evidence taught us that this formation is from upper Urakawan to Danian. Several gas and oil indications were also found in this formation.

\section{Oil and gas indications, hitherto reported in Hokkaido}

As already mentioned above, we have many Cretaceous oil and indications throughout this island.

Those indications are summarized in next page, list 3.

It is natural that those indications are most abundant in the Hakobuchi horizon, the uppermost horizon of the Yezo group, and are especially numerous in southern part of the Yezo geosynclinal basin. Gas indication in the Nemuro group, which was found in the boring well in the Taiheiyo Coal-mine is now utilized as town gas of Kushiro, its production is now $5,000 \mathrm{~m}^{3} / \mathrm{d}$.

\section{Oil and gas indications, recently discovered}

Thick Cretaceous sediments, over 5,000m thick from Hakobuchi to Lower Yezo were accumulated in Ishikari Kanayama district, extending from Oyubari and Yamabe districts. However no oil and gas indication have ever been reported from this area.

Last year (1968) 4 gas and 2 oil indications were found, especially the most interesting thing is a gas indication from sandstone of Shuyubari formation, Sorachi stage.

Formally only one uncertain information of gas indication from the Sorachi group was reported from diabasic rock of the Shimokawa mine $(\mathrm{Cu}$, $\mathrm{Pb}, \mathrm{Zn}$ ) Kitami district.

The discovery of gas indication of the recent is the first time which is found in the normal sediments of the Sorachi Group. 
List 3

oil seapage $\hat{\sigma}$ gas indication $\diamond$ oil smell

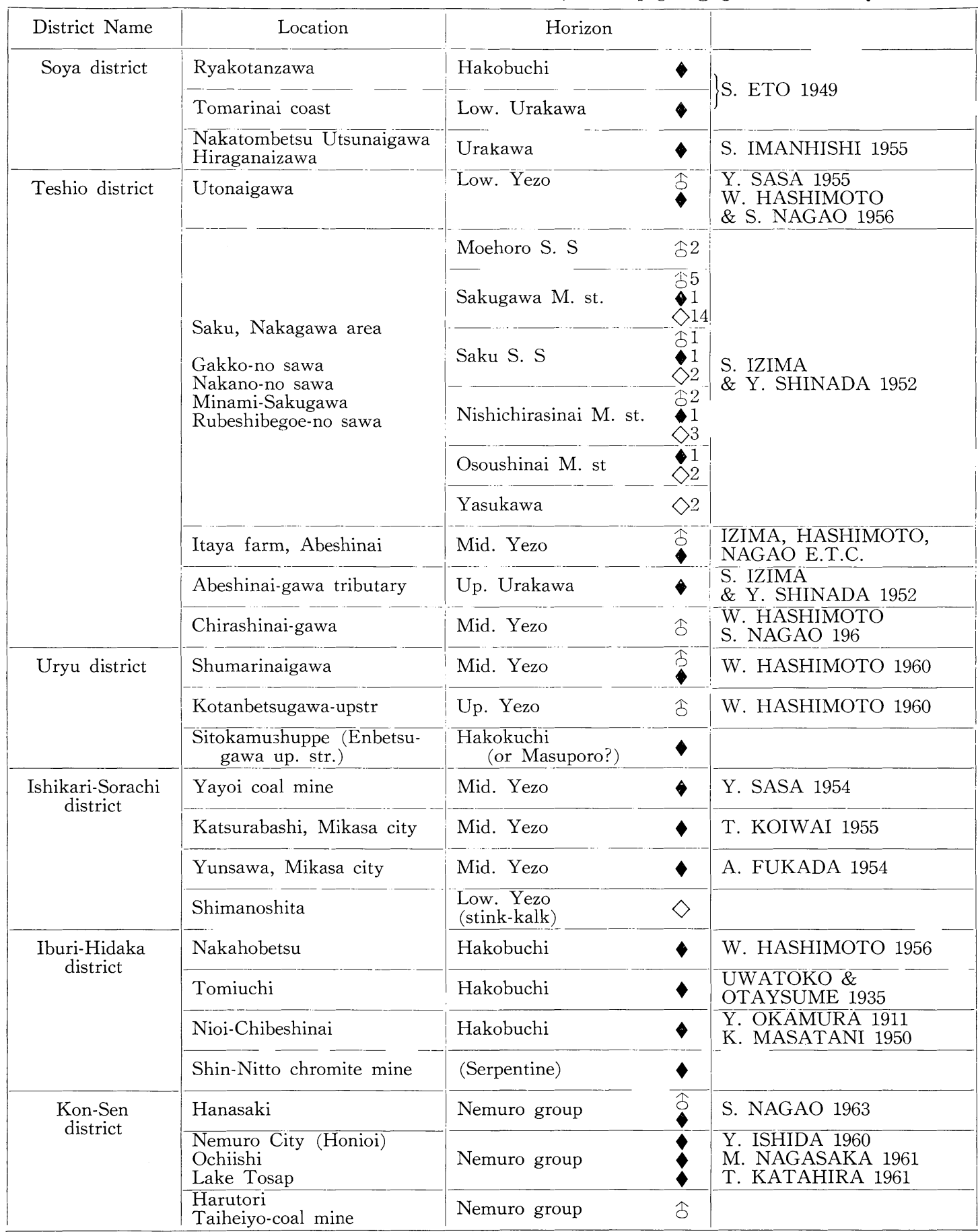

Those oil and gas horizons are also summarized as follow.

10 in Hakobuchi group (contain Nemuro)

6 in Upper Yezo group

9 in Middle Yezo group

3 in Lower Yezo group 
Those indications are as follows.

1. Oil indication in blackshale of the Upper Yezo group, 2,550m from west entrance in the Shin-noborikawa tunnel of the Momijiyama railroad line, Hobetsu viliage. Gas indication in the same horizon, $2,250 \mathrm{~m}$ in the same tunnel.

2. Oil indication in the Hakobuchi sandstone, $2,250 \mathrm{~m}$ from west entrance in the Noborikawa tunnel of the Momijiyama railraod line.

3. Gas indication in sandstone of the Shuyubari formation, $1,398 \mathrm{~m}$ from west entrance in the Onitoge tunnel of the Momijiyama railraod line, Shimekappu village.

4. Gas indication in boring well of Pankeshuru, Smimekappu village.

Oil indication in the Shin-noborikawa tunnel was found from cleavage in black shale of the Upper Yezo, and was orange-yellow coloured light oil, very similar to the oil from Katsuragawa, Mikasa town. Gas indication was also found in the same black shale about $300 \mathrm{~m}$ from this side of the oil seapage.

In the Onitoge tunnel, the west side of entrance is occupied by the Kawabata formation of Neogene age. Grayish hard sandstone of the Shuyubari formation, the upper part of the Sorachi group is covered by the Kawabata dark gray shale with basal unconformity.
PL. 3. Geological Map of the Vicinity of 3 Tunnels

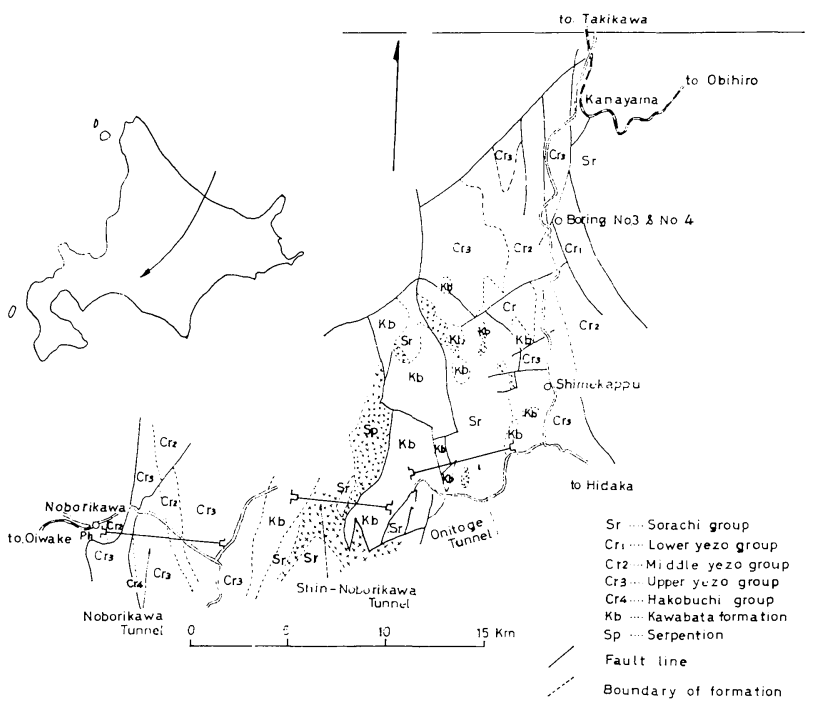

Gas indications were observed at 2 points, one is near unconformity plane and the other is in the hard Shuyubari sandstone, the former may be considered from the Kawabata shale, however, the latter is evidently from the Shuyubari group. A gas explosion accident is recorded in this tunnel on June, 1943 by those gas leakage. In the vicinity of 2 well points of Shimekappu village, reversal sandstone and shall of the middle Yezo group develop widely, and the formation is arranged like imbricate pattern by many reversal

PL. 4. Geologic Section of the Noborikawa Tunnel, Momijiyama Line

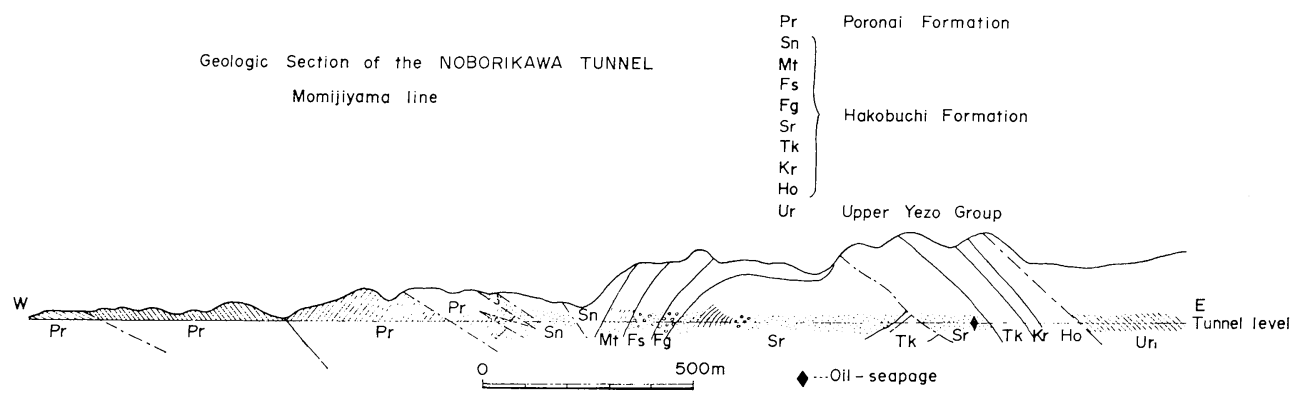

PL. 5. Geologic Section of the Shin-Noborikawa Tunnel

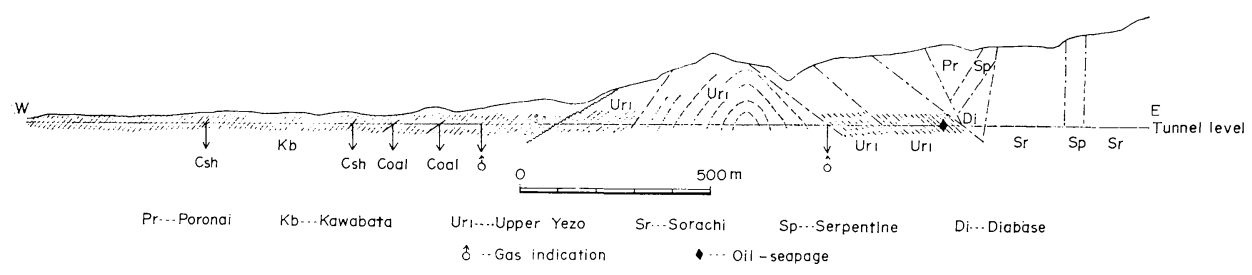


PL. 6. Geologic Section of the Oni-Toge Tunnel

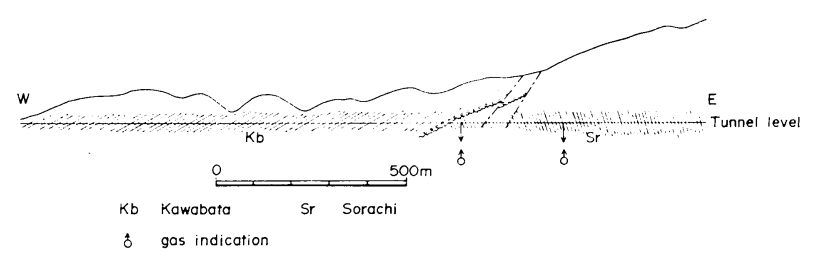

PL. 7. Geological Map along River Pankeshuru

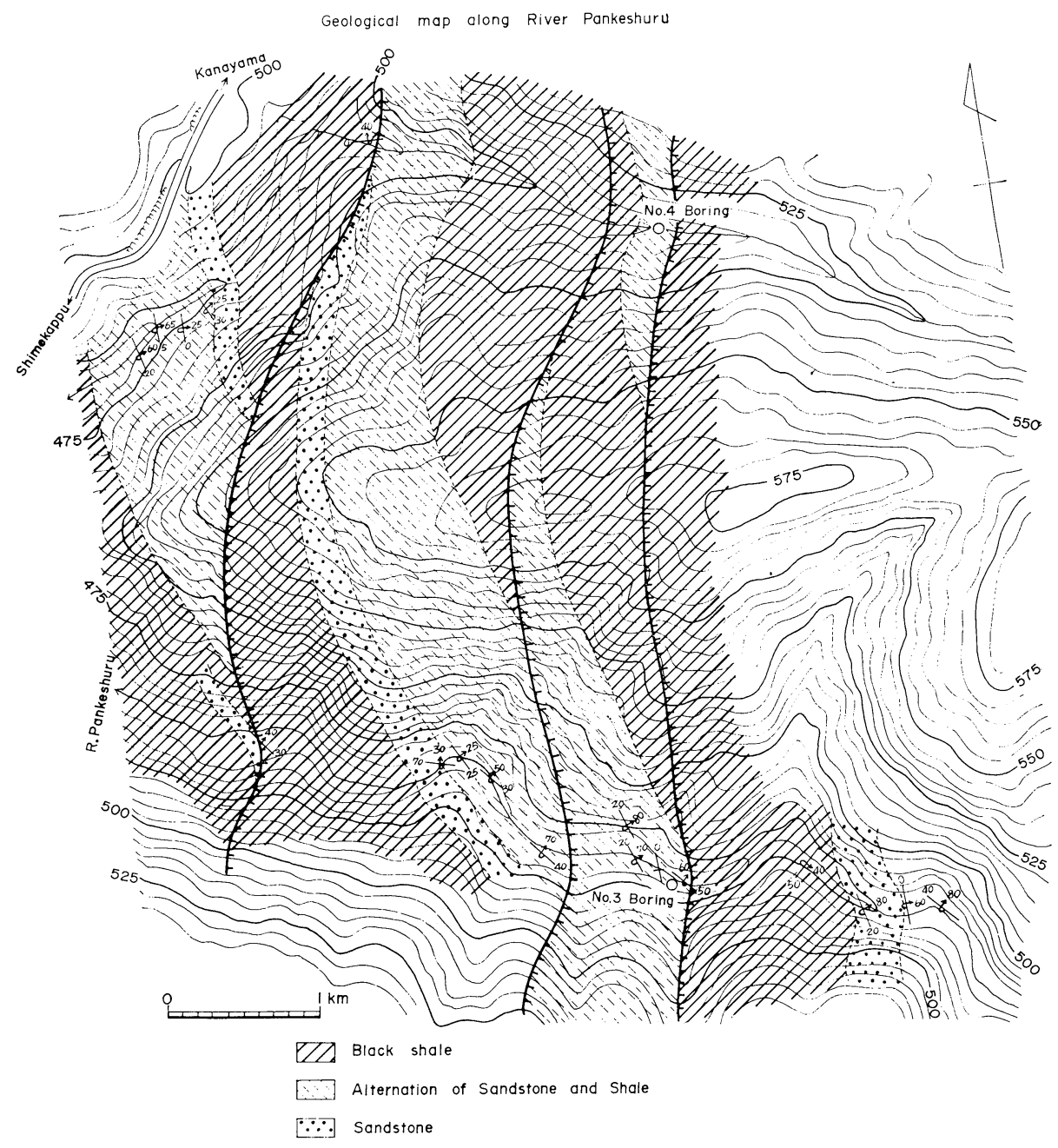

faults of N-S trend.

2 wells, No. 3 and No. 4 met with a same reversal fault plane, and gas indication was observed in both boring wells, No. 3 boring is at the depth of $50 \mathrm{~m}$ and No. 4 is of $13 \mathrm{~m}$.

Gas amount was $1-2 \mathrm{~m}^{3} / \mathrm{d}$ and water accompanied was $0.5-1 l / \mathrm{min}$. After analytical examination of this water, cl content was proved only
$9-13 l / \mathrm{mg}$, and the water is considered to be derived from somewhere along the fault plane, and not a product of in-situ.

As mentioned above, we can understand that the oil and gas from the Shin-Noborikawa Tunnel are clearly in situ. Those were derived from the massive black shale of the Upper Yezo group and oozed from its cracks. The oil indications of the 
Hakobuchi holizon in the Noborikawa Tunnel may also derived from underlying Upper Yezo black hale. One of the indications from the Sorachi group is obscure, because this indication is very near to the Kawabata formation of Neogene age, however the other it undoubtedly from gray sandstone of the Shinyubari formation. The possibility of oil and gas reservoir in the Sorachi group encourages the prospection of the basal sandstone (Moehoro horizone) of the Lower Yezo group.

\section{Recent situation for Cretaceous oil and gas exploration}

The volition for Cretaceous oil in Hokkaido has been elevated once or twice in the past time, however, all was resulted in no effective achievement.

As has already mentioned above, almost of the places of indication were discovered in the area where the formation had received several tectonic movements. So it is very difficult to conclude that the very place of indication is a suitable area for oil and gas preservation immediately. However, taking reference to those indications, we were taught that Oil and Gas shall be preserved in some suitable horizon in the area of having more gentle structure.

In Tenpoku district the western territory where Cretaceous formation is covered by the Neogene Tertiary formation, and in the central district the Cretaceous formation which is covered by the Ishikari coal bearing formation are considered to be hopeful for Oil and Gas reservation.

Taking consideration of the Yezo geosynclinal sedimentation, the most fruitful region for oil and gas is in the marginal area of its sedimentary basin and not in its center.

The Cretaceous formation under the Ishikari coal field attracts very strong attention of many geologists, and the geological sections, which have already been published taught us that the Lower and Middle Yezo groups are comparatively thin and the Upper Yezo group and the Hakobuchi group are rather thick in E-W section from Yubari to Sorachi.

It will be an interesting theme of the future that what is the structure of the Cretaceous formation under the gentle Tertiary strata from Horokanai to Yubari where the Middle to the Upper Cretaceous is thick.

In Soya and Tempoku districts, comparatively gentle structures are sometimes left in Cretaceous territory like Soya mountain range, and also in in Nemuro district we can see some suitable anticline in the Nemuro group.

One thing that must keep in memory is that the underlying Cretaceous structure is not always the same as the overlying Neogene Tertiary structure.

The study of the Cretaceous formation under the Tertiary strata is just started in very recent. We have many problems challenging to us for getting clear idea of oil and gas under the Ishikari coal field.

We have heard that a certain mining company recently having a plan to explore the Cretaceous oil under the Ishikari coal field, therefore effective and rapid study are urgently needed to solve this problem.

\section{References}

Hashimoto. W., 1952, The Geology of the Jurassic sediment in Hokkaido: Special Series of the Geol. Survey of Japan (B)

Hashimoto. W., 1954, The Sedimentation and the Deformation in the Mesozoic era of Hokkaldo: M.S.

Hashimoto. W., 1958, The Consideration on the Gyocyncline of the Yezo-Sachaline area: Memorial of Doc. Fujimoto's 61 years Anniversary.

Hashimoto. W., 1960, Varions problems on the geological formation of the Pre-Lower Yezo group: Memorial of Doc. Hanzawa's Anniversary.

Hashimoto. W., 1962, Cretaceous oil in Hokkaido Chikashigen No. 15, 16, 17.

Ijima. S. and Shinada. N., 1952, Northern district of the Abeshinai Oil Field in Teshio, Hokkaido: Geol. Surv. Jap. Vol. 3, No. 12.

Kinoshita, K., The Cretaceous Orogenic Cycles and Sedimentary Basins in Hokkaido: Jour. Jap. Ass. Pet. Tech. Vol. 28, No. 2.

Matsumoto. T. 1942-43, Fundamentals in the Cretaceous Stratigraphy of Japan: Mem. Fac. Sci., Kyushu Univ. Sev. D. Vol. 1, Vol. 2.

Matsumoto. T., 1954, The Cretaceous System in the Japanese Island: Jap. Soc. for Prom. Sci. Tokyo.

Matumoto. T., 1959, Zonation of the Upper Cretaceous in Japan: Mem. Fac. Sci. Kyushu Univ. Ser. D. Vol. IX, No. 2.

Nagao, S., 1963, Fundameutals of the Cretaceous oil in Hokkaido: Geol. Surv. of Hokkaido No. 31.

Nagao. S., 1965, Regarding Jurasso-Cretaceous formation in Hokkaido with special reference to the unknown Mesozoic strate: Geol. Surv. of Hokkado No. 33

Osanai, H. Nagao, S. Hashimoto, W. 1958, Kanayama 
Geol. Map. Sheet: Hokkaido Dev. Board.

Tanaka, K., 1963, A study on the Cretaceous Sedimentation in Hokkaido Japan: Geol. Surv. Jap., Report No. 197.

\section{約 要}

最近発見された $2 \sim 3$ の白亜紀油・ガス徴 について

\section{長尾捨一・田中寿雄}

北海道における白巠紀層中の油・ガス徴は古くから知 られており，その報告や研究もかなりの数にのぼってい る。しかしながら，油田・ガス田の見地からのこれらの 研究は, 最近やつと本格的な研究が始められたばかりで ある。従来知られている徴候は大別して, 宗谷 3 , 天塩 5 , 雨竜 3 , 石狩・空知 4 , 胆振・日高 4 , 根釧 5 とな り, 北は宗谷から南は日高まで, 白亜系分布地域のほとん どに油・ガス徴が認められる。またこれらを層準的に見 れば下部蝦夷層群 3 , 中部蝦夷層群 9 , 上部蝦夷層群 6 , 函淵層群 10 となる。1968 年度には以上のものに追加し て, 新らしく 2 つの油徴, 4 つのガス徴が発見された。 油徴は上部蝦夷層群と函淵層群に，ガス徴は上部蝦夷層 群 1 ，中部蝦夷層群 2 ，空知層群 1 である。このうち,
空知層群主夕張層の硬質砂岩からのガス徴は, 從来確実 に把握できなかった空知層群中の徴候として興味あるも ので, 下部蝦夷層群基底の萠幌砂岩も, 貯留岩として考 虑される可能性のあることを示している。北海道の下部 白亜紀層は空知層群の主夕張層から始まるとされている ので, 白亜系の全層準に亘って徴候が確認されたことに なる。今回発見された白严系の油はいずれも橙黄色軽質 の透明な油で, 他の白亜系の油とほとんど同様な性状を 示しており, ガス徴のうち，占冠村鬼峠のトンネル内で 涌出したものは，ガス爆発事故を起している。現在利用 されている白覀系起因の油・ガスは，道東大平洋炭礦の ボーリングによる根室層群汐見層からのガスで， 5,000 $\mathrm{m}^{3} / \mathrm{d}$ が釧路で都市ガスとして利用されている。これら の白亜系の油・ガス徴の大部分は, 地質的にかなり激し い擾乱をうけた地帯にあるので，これが，おとなしい第 三紀層下に伏在している地域が，今後の白亜系油・ガス 田として探査の対象となるであろう。石狩炭田下への白 覀系に対しては多くの人々が與味をもっている。最近こ の開発を目的とする計画が次第に熟してきているようで ある。このためには，われわれがなさねばならない数多 くの探査があり, それも急速な実施が要望されるのであ る。 